\title{
Comparative Analysis of Financial Advancements in Mongolia
}

\author{
Solongo Chuluunbat \\ Business School, Sun Yat-sen University, Guangzhou, China \\ Email: solongoo.chuluunbat@gmail.com
}

How to cite this paper: Chuluunbat, S. (2021). Comparative Analysis of Financial Advancements in Mongolia. Journal of Financial Risk Management, 10, 40-53. https://doi.org/10.4236/jfrm.2021.101003

Received: November 10, 2020

Accepted: March 20, 2021

Published: March 23, 2021

Copyright $\odot 2021$ by author(s) and Scientific Research Publishing Inc. This work is licensed under the Creative Commons Attribution International License (CC BY 4.0).

http://creativecommons.org/licenses/by/4.0/

\section{(c) (i) Open Access}

\begin{abstract}
This paper looks into the financial advancements made by Mongolia over the $20^{\text {th }}$ century towards the $21^{\text {st }}$ century. It also looks into the global financial trends with an insight into the various factors contributing to the changes and developments in the global financial sector. It has analyzed the financial situation of Mongolia in the $20^{\text {th }}$ century and how it has changed through various reforms and revolutionary measures in the $21^{\text {st }}$ century. Various financial indicators have been compared between the last century and this century to identify the advancements made in the financial industry. It has identified various challenges in the financial sector of Mongolia and offered recommendations on how to solve these challenges.
\end{abstract}

\section{Keywords}

Financial Advancements, Finance Trends, Financial Situation,

Financial Reforms, Financial Indicators

\section{Introduction}

A country's financial advancements look into the ways it has improved in the borrowing, lending, creation and management of its money. The financial status of a country highly dictates the economic growth of the country because all the activities involving a country's economy generally revolve around its money (Reid, 2010). Mongolia is considered one of the fastest growing economies of the Asian region. Mongolia was even at one time in 2011 identified as the fastest growing economy in the world with double digits of $17 \%$ growth rate (Asian Development Bank, 2008). The country's economy is highly depended on minerals with mining activities involving copper, gold, and coal among others. The mining activities in Mongolia are about $90 \%$ of their total export. The location of 
the country as a landlocked country does not provide many advantages and therefore limits its business partnerships. This disadvantage has limited its partnerships leaving China as its most vibrant financial partner and does more that $90 \%$ of its export deals with China. Right now, Mongolia is at $127^{\text {th }}$ position in the world ranking in terms of economic strength with a freedom score of 55.9 on the economy (Heritage, 2020). It is thirtieth largest economy among the forty-two Asian-Pacific countries, just behind India and Bangladesh. The financial sector largely takes care of the institutions and markets through policies and regulations in order to allow transactions in all levels and therefore extend credit. This sector is fundamentally responsible for risks management, trade facilitation and ensuring diversity. It is also responsible for savings facilitation through pooling and mobilization. Thirdly, financing the corporate sector while ensuring governance and setting up a monitor for the same. Fourthly, it ensures the smooth flow of exchange between various goods and services. Finally, it is the responsibility of the financial sector seeks information on possible investments and ensuring the investment has enough capital allocation.

Financial advancements have played a huge role in the economic development of every country. The ability of this sector to accumulate capital while ensuring the maximization of allocation, facilitation of maximum savings through promotion of high saving rates, spread investment information and opportunities, and foreign capital encouragement and investment. The other importance is faster economic growth rate that is expanded for longer periods of time. Another important aspect of this sector is the promotion and provision of financial support to the small and medium sized enterprises (SMEs). There are various advantages attributed to SMEs including job opportunities through their labor-intensive requirements.

\section{Literature Review}

Understanding the global financial position gives a clear view of the performance of Mongolia as a country. The global financial trends have been evolving day in day out (Barro, \& Sala-i-Martin, 1992). A country's economic performance is highly dependent on the capital flows it is exposed to and the ability and levels of sophistication of a country's domestic financial system to deal with these huge capital flows. Any country is able to expand its domestic financial system if it is more exposed to international capital flows.

Since the end of the $20^{\text {th }}$ century, the world has seen a lot of development in both financial and economic sectors. The end of the Cold War ushered in a new era where the United States emerged as the world's greatest economy and a super power (Yueh, 2020). This concurrently ushered in the reign of the US dollar as the dominant currency that the world uses to price oil and energy products, foreign investments, and the international commodities. These changes also saw the rise of new world economies like China in a significantly short time. At the beginning of the $21^{\text {st }}$ century, the world came under shock of the collapse of the 
financial markets in one of the largest financial crisis of this century (Yueh, 2020). This crisis shifted the financial focus to the emerging economies rather than the developed ones. China benefited a big deal from the evolution in their financial strategy of a consumer-driven economy rather than an export-oriented strategy. Strategies like deregulation in the financial sector and offshoring to foreign cheap labor sources which are readily available in the developing countries has seen a move from the so-called giant countries to the most populated ones in the world. The less populated countries have less consumer power which will require them to seek a way to integrate in the global system through various ways such as trade agreements.

This era has also seen a global development in the financial sector brought about by the emerging new technologies in the provision of both banking and financial services. These are generally referred to as financial technologies (fintech) (Bakkar, n.d.). These technologies have revolutionized the buyer seller interactions, the overall business model, and the current and future financial sector. This is generally viewed in technological advancements such as the internet of things (IoT), the field of artificial intelligence, the block chain technologies, and cloud computing. Another change has been realized in the consumer behaviors as the technology grows. Many people have changed in the way they buy or sell commodities and exchange currencies as they align themselves with the current societal developments. The thresholds of financial qualifications have been lowered by these technologies ensuring the growth and development of many startup companies in the financial sectors such as banking. People can readily access loans through simple mobile applications that do not even require one to have a good credit score. The developments in the fintech sector has seen the cost of accessing data and information lower as times go by through the assistance of such technologies as artificial intelligence analytic tools (Bakkar, n.d.).

Financial technologies have helped the financial services rise through various ways such as easing of money borrowing and lending. This has been promoted by the decentralization and transparency in the borrowing sector such as the development of peer-to-peer borrowing and crowdfunding (Bakkar, n.d.). The changes in the traditional borrowing methods have enabled many people who would otherwise not qualify have access to loans and grants. The other way is the revolution in the financial markets. The new developments have seen a change in the financial markets like automation in the trading markets enabled by the artificial intelligence and the evolution of the stock exchange sectors (Bakkar, n.d.). Private sectors and individuals can now access these markets as opposed to the past where only corporations were allowed. Fintech has also seen changes in ways of asset management automation and various tools available for data analysis and information processing. Regtech tools have enabled regulation and control of the financial sector to keep away fraudulent business of the market. Threat elimination is easy through real time threat identification and mitigation and prevention of breaches help keep the sector a float. 


\section{Methods}

\subsection{Financial Development Measurement}

There are four variables that are used to measure the level of financial development of a given country as described by World Bank's Global Financial Development Database. These variables include stability, depth, efficiency and access (The World Bank, 2016). These variables are put into a measurement under the two main financial components of institutions and markets.

\subsubsection{Financial Depth}

According to Table 1, the financial depth of a country is measured through various ways where they try to evaluate the total banks and other financial institutions as they compare to the economic output of the country Financial Depth (The World Bank, 2016). The ratio of private credit to the gross domestic product tries to measure the level of borrowing by the private sector. Neither very high nor very low of these values are very good for a country (The World Bank, 2016). In percentage, the amount of money lends to the private sector in comparison to the Mongolian GDP, the range was at around 50\% in 2019 as shown in Figure 1 (Statista, 2020). However, this has been fluctuating from time to time for the last decade as indicated in the figure. The gross value added refers to the financial production in its efforts to contribute to the gross domestic product.

In the total asset ratio to the gross domestic product, it is considered more comprehensive for incorporating the government credits and bank institutions assets (Statista, 2020). The bank assets to GDP ratio for Mongolia have been on the rise in the $21^{\text {st }}$ century. For the last few years, it has been in the $60 \%$ as a percentage of the country's gross domestic product as indicated by Figure 2 (The Global Economy, n.d.).

Table 1. Financial depth (The World Bank, 2016).

\begin{tabular}{ll}
\hline \multicolumn{1}{c}{ Financial Institutions } & \multicolumn{1}{c}{ Financial Markets } \\
\hline $\begin{array}{l}\text { The ration of credit in the private sector } \\
\text { to the gross domestic product }\end{array}$ & $\begin{array}{l}\text { The ratio of an addition of stocks capital and the } \\
\text { debt securities of the domestic private sector to } \\
\text { gross domestic product }\end{array}$ \\
$\begin{array}{l}\text { The ratio of total assets belonging to the } \\
\text { financial institutions to the gross domestic } \\
\text { product }\end{array}$ & $\begin{array}{l}\text { The ratio of the debt securities for the private } \\
\text { sector to the gross domestic product }\end{array}$ \\
$\begin{array}{l}\text { Ratio of money and quasi money to the } \\
\text { gross domestic product (M2/GDP) }\end{array}$ & $\begin{array}{l}\text { Ratio of debt securities for the public sector to the } \\
\text { gross domestic product }\end{array}$ \\
$\begin{array}{l}\text { The ratio of deposit to the gross domestic } \\
\text { product }\end{array}$ & $\begin{array}{l}\text { The ratio of debt securities for the } \\
\text { international sector to the gross domestic product }\end{array}$ \\
$\begin{array}{l}\text { Gross value added to the gross domestic } \\
\text { product }\end{array}$ & $\begin{array}{l}\text { Ratio of the capitalization in the stock market to } \\
\text { the gross domestic product }\end{array}$ \\
\end{tabular}


Domestic credit to private sector as share of GDP in Mongolia

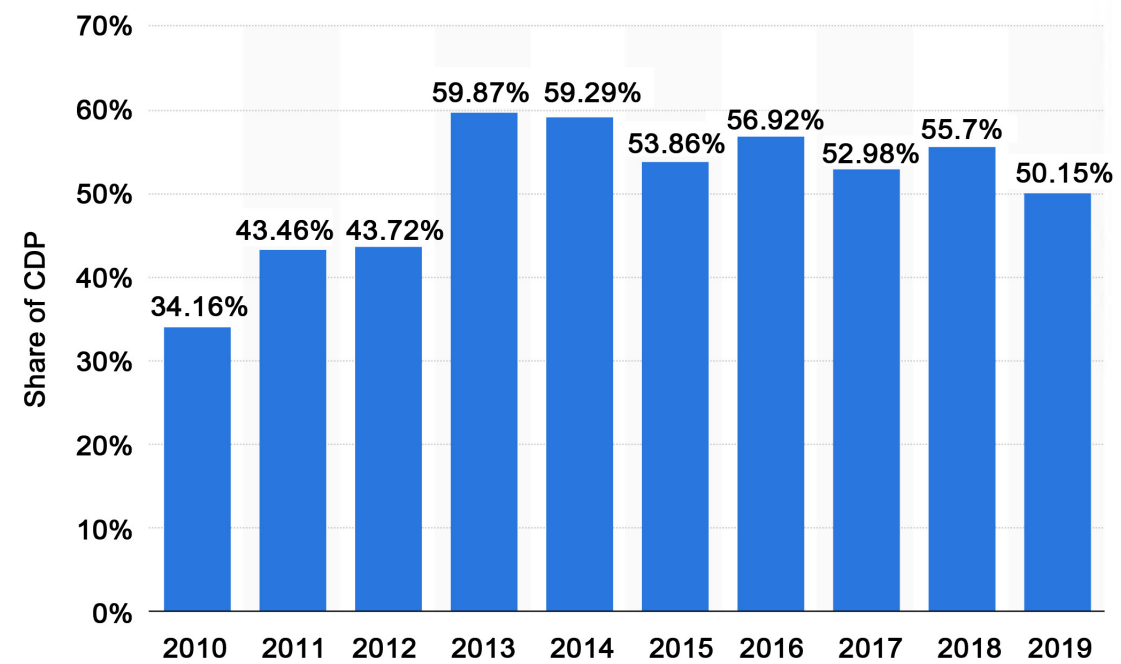

Figure 1. Private credit to GDP ratio (Statista, 2020).

Mongolia - Bank assets to GDP

80

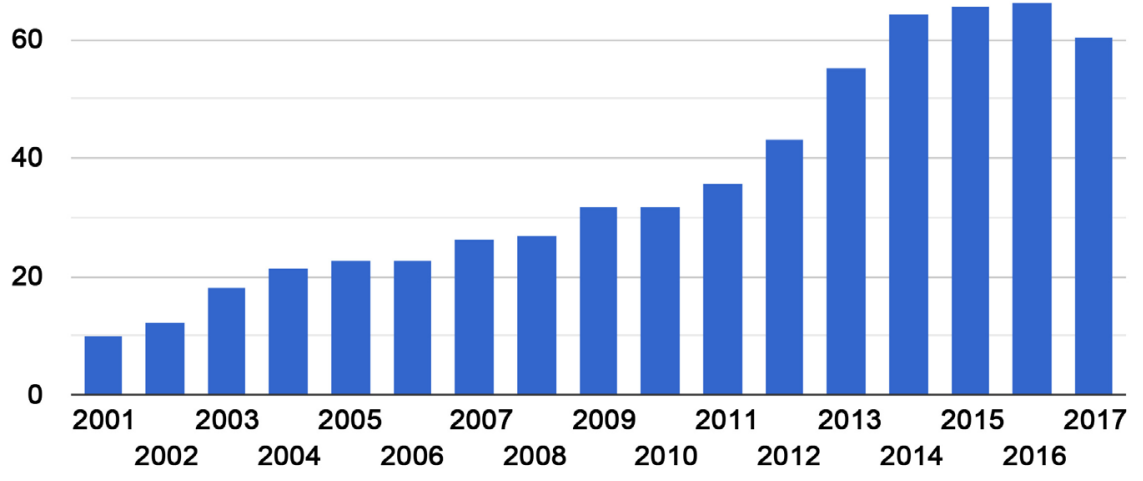

Figure 2. Bank assets to GDP ratio (The Global Economy, n.d.).

The M2/GDP ratio of a country indicates the capacity it has in terms of growth productivity as per Figure 2 (The Global Economy, n.d.). The money supply for Mongolia has been on a constant rise for the last decade except for this year where it has been affected by the ongoing Covid-19 crisis. Figure 3 gives a clear picture of the supply since 2010 (Trading Economic, 2020a).

According to Figure 4, the deposit to GDP ratio for Mongolia has also followed the same increasing trend for over a decade now as indicated below in Figure 4 (Trading Economic, 2020b).

Figure 5 states that in the financial market, the private sector securities for Mongolia in comparison to the gross domestic product had fallen as low as 7.5\% at around 2017 (Trading Economic, 2020c). However, this has been up and down along the last decade as the figure indicates. The capitalization to 
in March of 2020.source: Mongolbank

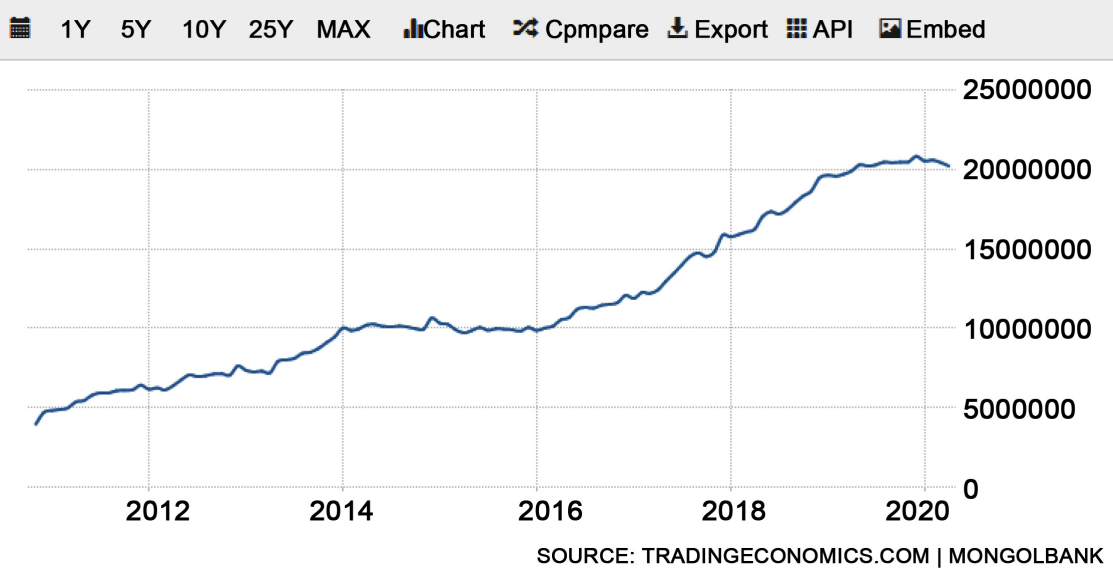

Figure 3. M2/GDP ratio (Trading Economic, 2020a).

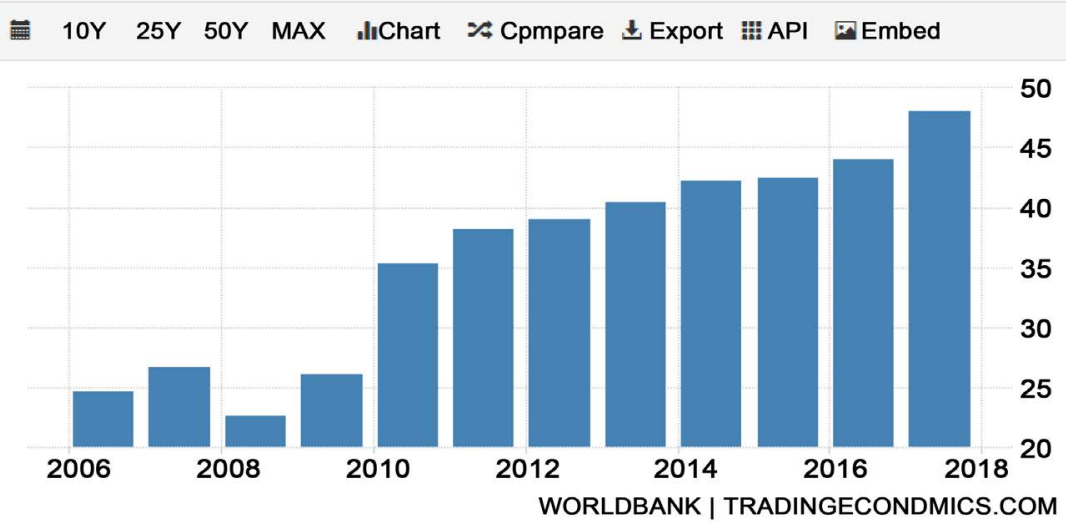

Figure 4. Deposit to GDP (Trading Economic, 2020b).

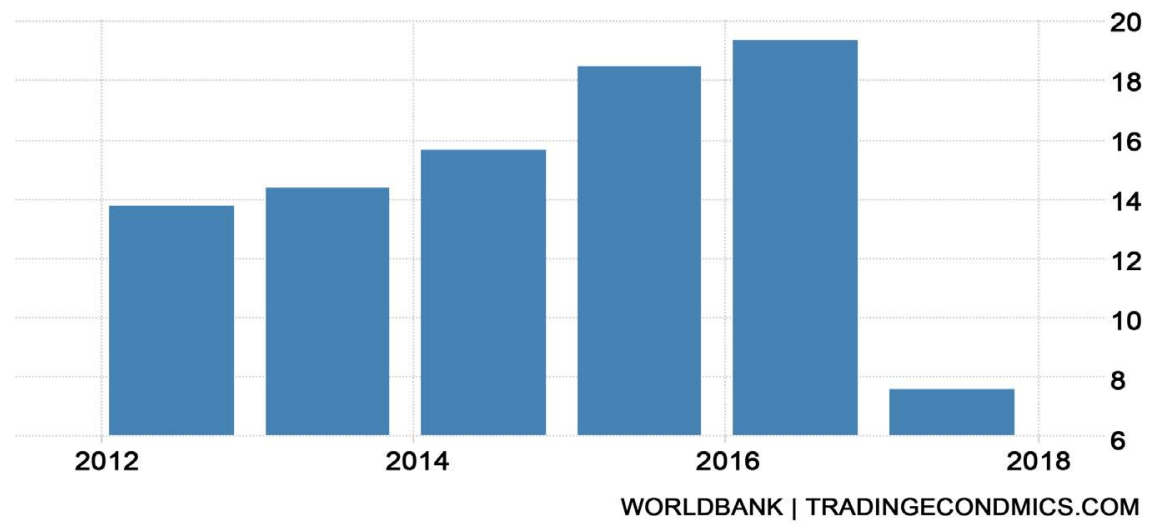

Figure 5. Domestic private debt securities to GDP ratio (Trading Economy, 2020d).

gross domestic ratio in percentage ranges at $7 \%$ for the last two years as shown in Figure 5 (Trading Economy, 2020d). This has been a drop form their all-time high of $16 \%$ achieved in 2011 (CEIC, n.d.).

As for the government borrowings, the public debt securities to the gross do- 
mestic product ratio has been rising over a long period of time. In 2017, it was estimated to be just over $50 \%$ in percentage form as indicated by Figure 6 (Trading Economy, 2020d).

\subsubsection{Financial Access}

The aspects in Table 2 are used to measure the financial development in terms of financial access both in the markets and the institutions (The World Bank, 2016).

\subsubsection{Financial Stability}

Table 3 talks about the financial efficiency parameters. These are inclusive of the capacities of the several aspects of the economy. Financial efficiency means being able to successfully sustain the needs in the economy.

The following aspects mentioned in Table 4 are useful in measuring the stability

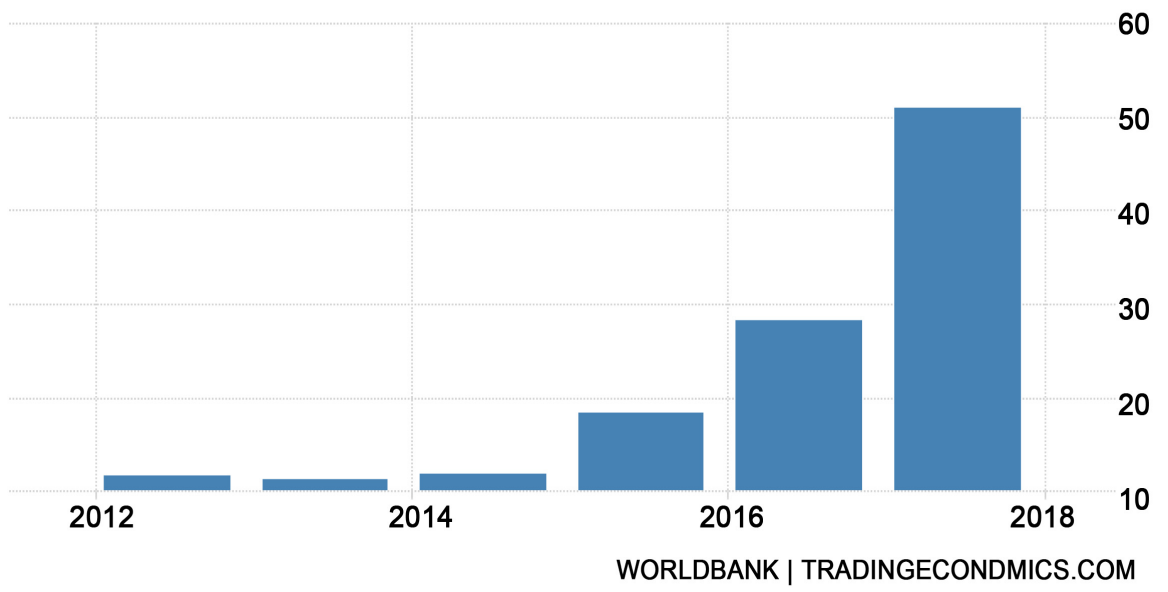

Figure 6. Public debt securities to GDP ratio (Trading Economy, 2020d).

Table 2. Financial access (The World Bank, 2016).

\begin{tabular}{ll}
\hline \multicolumn{1}{c}{ Institutions } & \multicolumn{1}{c}{ Markets } \\
$\begin{array}{ll}\text { The number of adults who have bank accounts } \\
\text { in a batch of a thousand people (commercial } \\
\text { banks) }\end{array}$ & $\begin{array}{l}\text { The measure of market capitalization without } \\
\text { considering the ten largest companies in the } \\
\text { country (as a percentage) }\end{array}$ \\
$\begin{array}{l}\text { Assessment of the number of branches of } \\
\text { commercial banks by the hundred thousand } \\
\text { of the adult customers }\end{array}$ & $\begin{array}{l}\text { Except for the top ten companies, measure the } \\
\text { value traded in the form of percentages of the } \\
\text { total trade. }\end{array}$ \\
$\begin{array}{l}\text { The percentage of the population who hold } \\
\text { bank accounts }\end{array}$ & $\begin{array}{l}\text { For a period ranging from three months to ten } \\
\text { years, measure the yields of the government } \\
\text { bonds for the same period }\end{array}$ \\
$\begin{array}{l}\text { The number of firms that have lines of credit } \\
\text { as a percentage of the total firms }\end{array}$ & $\begin{array}{l}\text { Calculate the ratio of domestic to that of the } \\
\text { debt securities in total }\end{array}$ \\
$\begin{array}{l}\text { The percentage of firms with lines of credit in } \\
\text { comparison to the small firms }\end{array}$ & $\begin{array}{l}\text { Calculate the ratio of private to that of the debt } \\
\text { securities in total }\end{array}$ \\
& $\begin{array}{l}\text { Finally, calculate the corporate bond issues of } \\
\text { the new corporation as a ratio to the gross } \\
\text { domestic product }\end{array}$
\end{tabular}


Table 3. Financial efficiency (The World Bank, 2020).

\begin{tabular}{|c|c|}
\hline Financial Institutions & Financial Markets \\
\hline The margin on the net interest & $\begin{array}{l}\text { The turnover ratio indicating the ease of sale } \\
\text { of the shares in the stock market }\end{array}$ \\
\hline $\begin{array}{l}\text { The spread of the margin between lending } \\
\text { and the deposits }\end{array}$ & $\begin{array}{l}\text { The stock price synchronicity and the } \\
\text { co-movement }\end{array}$ \\
\hline $\begin{array}{l}\text { The ratio of the income without interest to } \\
\text { the total income }\end{array}$ & The trading on the private information \\
\hline $\begin{array}{l}\text { The total overhead costs measured as a } \\
\text { percentage of the total assets }\end{array}$ & The impact on the price \\
\hline $\begin{array}{l}\text { The possibility of making profits as a total of } \\
\text { returns from the assets and equity }\end{array}$ & The cost of either transaction or liquidation \\
\hline \multirow[t]{3}{*}{ The boone indicator or the $\mathrm{H}$-statistics } & $\begin{array}{l}\text { He stretch of government bond in terms of } \\
\text { quoted bid to ask }\end{array}$ \\
\hline & $\begin{array}{l}\text { The total private and public turnover bond in } \\
\text { the security exchanges }\end{array}$ \\
\hline & The efficiency and ease of being able to settle \\
\hline
\end{tabular}

Table 4. Financial stability (The World Bank, 2020).

\begin{tabular}{ll}
\hline \multicolumn{1}{c}{ Financial institutions } & \multicolumn{1}{c}{ Financial Markets } \\
\hline $\begin{array}{l}\text { The standard score generally identified } \\
\text { as z-score }\end{array}$ & $\begin{array}{l}\text { The volatility of indexes in both stock price } \\
\text { and sovereign bond }\end{array}$ \\
$\begin{array}{l}\text { The ratio of capital to risks asset } \\
\text { Test for the stock price and sovereign indexes } \\
\text { skewness }\end{array}$ \\
$\begin{array}{l}\text { The ratio of charges incurred in loan } \\
\text { impairment to the total assets }\end{array}$ & $\begin{array}{l}\text { The possibility of manipulation of the earnings } \\
\text { The liquidity ratio }\end{array}$ \\
$\begin{array}{l}\text { Other important aspects include the position } \\
\text { of foreign exchange to the total capital among to earnings ratio } \\
\text { others }\end{array}$ & $\begin{array}{l}\text { The duration } \\
\text { The domestic and international ratios of short }\end{array}$ \\
& $\begin{array}{l}\text { Terms to the total bonds } \\
\text { The correlations on the main bonds returns } \\
\text { especially for the economic giants such as the } \\
\text { United States or China }\end{array}$ \\
\hline
\end{tabular}

of the financial sector of a country according to the World Bank's Global Financial Development Database (The World Bank, 2016).

The Z-score for Mongolia in 2017 was measured at 19.07 in 2017 as shown in Figure 7. There have been fluctuations in the past decade on this bank value with a highest value of 26 reported in 2006 (Trading Economy, 2019).

In the markets, the stock price index volatility for Mongolia has been constantly under a falling trend with an index of 49 a decade ago and 17 just three years ago (FRED Economic Data, 2019). Since the beginning of the $21^{\text {st }}$ century, Mongolia has posted an average of 53 percent in the volatility index as shown 


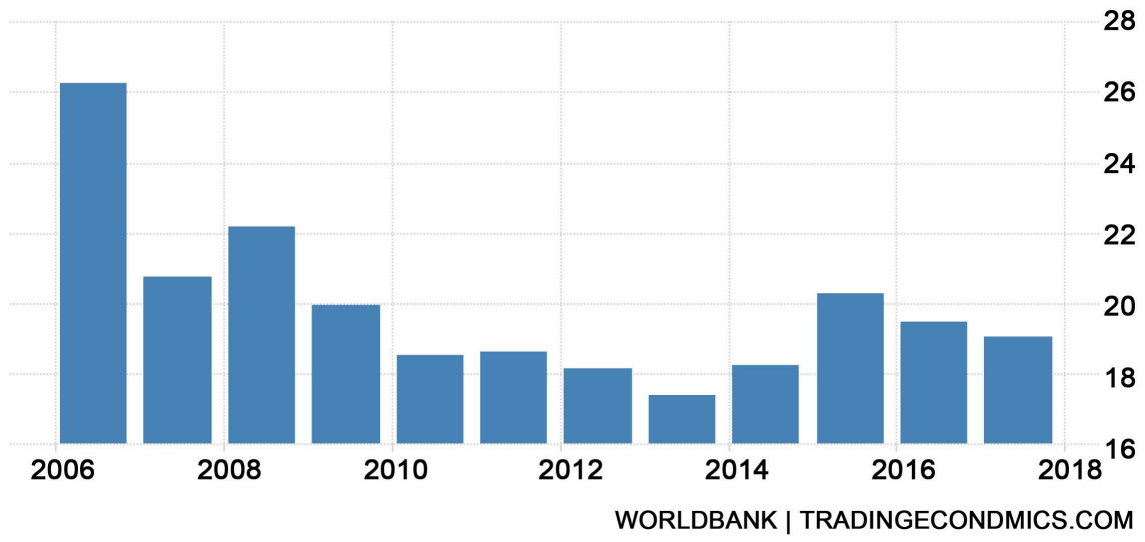

Figure 7. Bank Z-score (Trading Economy, 2019).

in Figure 8.

\subsection{Financial Performance for the $20^{\text {th }}$ Century}

The financial performance of Mongolia was in declining verge especially before the 1990s. In 1992, they adopted a new constitution which was a turning point for their economic performance. The transformed from a single-party system to a multiparty democracy which marked a new beginning. They began opening up their borders for new markets and begun experiencing new political stabilities. They invested a lot of resources and time in the reformation of the financial system by revolutionizing the banking sector of the country. These reforms ensured improved inflation rates and the overall growth in their economy. At around 1989, the contribution of the private sector was less than $4 \%$ (Asian Development Bank, 2008). Following the new financial improvements and the economic strategies employed in the $90 \mathrm{~s}$, the contribution of the private sector rose to over $70 \%$ of the gross domestic product by 1999 . This led to a positive growth rate in the country's economy to $3.2 \%$ from a negative growth rate (Asian Development Bank, 2008).

Mongolia went through a series of economic and financial crisis especially in 1994. At this time, the country had a very high unemployment rate with estimates of more than two hundred thousand people in a workforce of a million being unemployed. The consumer price index for this period was recorded as $3.8 \%$ from a $9.1 \%$ average the year before (Asian Development Bank, 2008). During these periods, the financial sector had very low economic contribution with the industrial sector taking the lion's share of 32\% of the GDP (Asian Development Bank, 2008). Prior to the 90s, Mongolian currency, Tugrik (T), was not convertible. The reforms introduced in these times saw the introduction of a conversion for the currency after servicing with two rates of transaction, commercial and noncommercial. Since then, the value of the Tugrik against the dollar has been revised severally.

The main economic indicators in those days included GDP growth rate that ran at 2.1 percent. The customer price index on inflation was at 66.3 percent. 


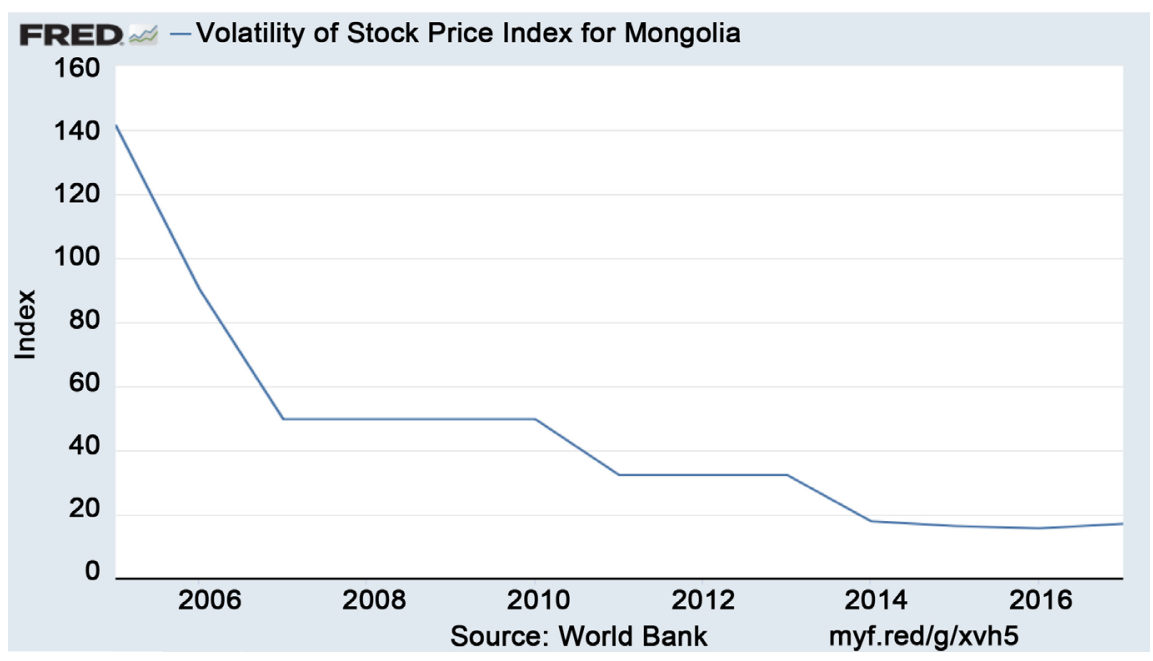

Figure 8. Stock price index volatility (FRED Economic Data, 2019).

Foreign credits and grants were at 111.4 percent (Asian Development Bank, 2008). The agriculture and industrial sectors were the main economic supports in this period with their percentage contribution to the gross domestic product running at 7.1 and 2.7 respectively (Asian Development Bank, 2008). The registered unemployment rates were very high. The import and export were at $\$ 362$ million and \$360 million respectively (Asian Development Bank, 2008). These were significant drops from what was being experienced in 1989. They were undergoing the costs of evolution in the financial sector and banking system changes.

\subsection{Financial Performance in the $21^{\text {st }}$ Century}

The dawn of the $21^{\text {st }}$ century in Mongolia came with a lot of changes and reforms beginning with the adoption of a new strategy named Medium-Term Strategy for Financial Sector Development aimed at reforming the financial sector in the next five years (Asian Development Bank, 2008). This came after a financial hiccup of the 1999 in the crisis of low prices of export commodities from the country. This reform was followed by the National Action Plan that was expected to reform the financial system through stabilization, encouraging the culture of saving, and ensuring growth of the stock exchange market. It also aimed to expand the range of services offered by the financial sector in Mongolia.

The Mongolian reforming of the financial sector has seen the gross domestic product of the country grow to triple its size from the last century. It has been regularly group among the fastest growing economies in the Asian region especially with boosts in both mining and the financial sectors. The growth and development have however had its challenges along the way especially the collapse of the financial market of 2009 and the current ongoing pandemic of corona virus which has affected all aspects of life globally (Tsetsenzaya, Xiawei, Hussain, \& Shaheen, 2019). The 2009 financial crisis was well handled by the Mongolian 
leadership with the help of many international financial institutions such as the International Monetary Fund and foreign country donors. The country then leaped the fruits of this good investments and relationships with a positive growth of $17.5 \%$ in the economy two years later (Tsetsenzaya, Xiawei, Hussain, \& Shaheen, 2019). However, this high growth rate has not been maintained due to various factors such as decrease in foreign investments especially from China. The hyperinflations experienced in the past century have been minimized and therefore a positive growth rate achieved.

There has been various programs implemented by the Mongolian government with an aim of strengthening Mongolian financial intermediaries, establishment of robustness in the financial sector through reforms and regulations, and establishing a market based financial sector for the country (Bank of Mongolia, 2012). Some of the main actions that the reforms established boundaries in the influences of the government on the credit decisions, and they also cultivated on the autonomy of the banks through revolutionizing the shareholders and management's responsibilities. These kinds of reforms saw a change in the commercial banks in the directions of credit procedures and policies, changes in the risk management techniques, and the means of gathering and managing information.

The country has benefited constantly from the financial system changes such as the inflation rates which have been on a downward trend (Trading Economics, 2020e). The reduced inflation rates shown in Figure 9 have helped in the maintenance of the positive economic growth rate. In September this year, the country recorded one of the lowest inflation rates of $1.7 \%$ even after the havocs of the Covid-19 crisis (Trading Economics, 2020e).

Another significant change is the growing GDP which was last recorded at $\$ 12,309.80$ after an adjustment using the purchasing power parity (PPP). The GDP per capita was recorded $t \$ 4350.20$ last year as in Figure 10 (Trading Economics, 2020f). Mongolia recorded a 34 percent of the world's average gross domestic product (Trading Economics, 2020f).

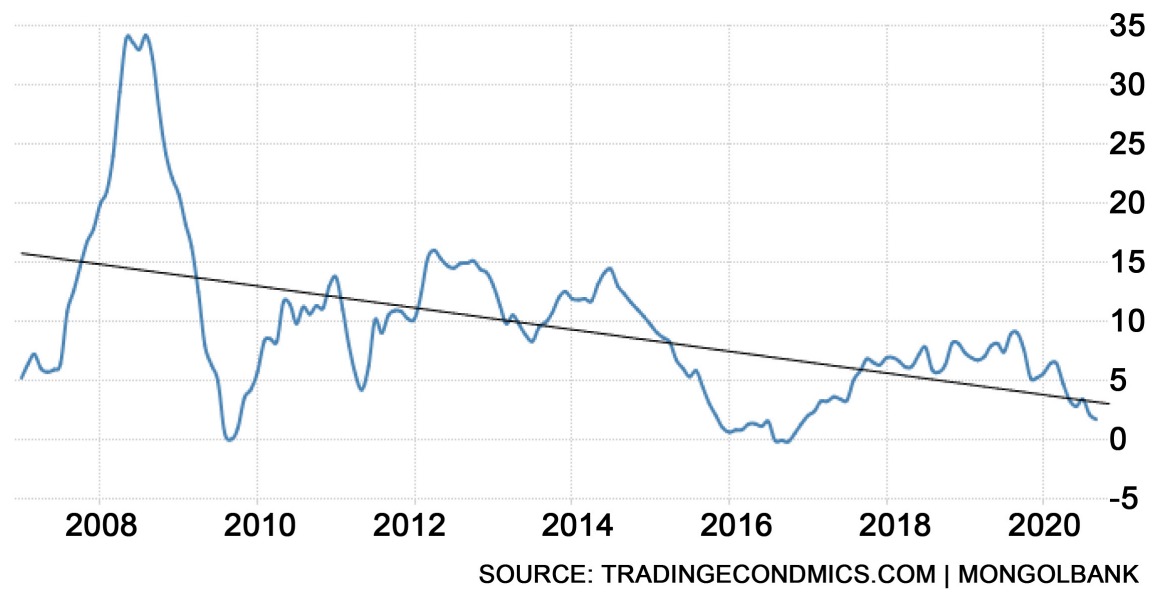

Figure 9. Mongolian inflation rate (Trading Economics, 2020e). 


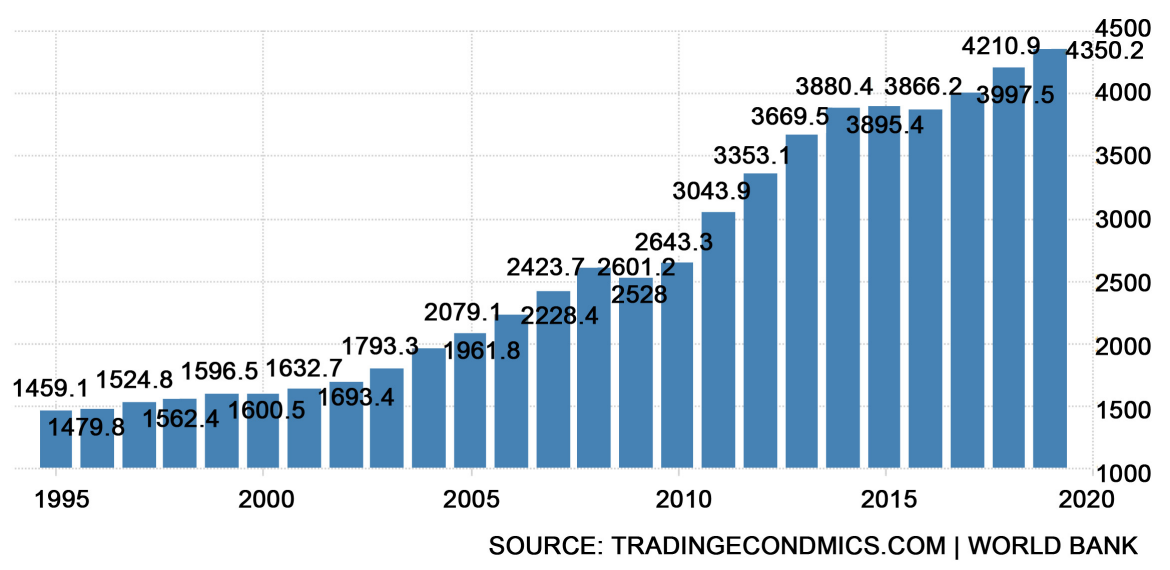

Figure 10. Mongolian GDP (Trading Economics, 2020f).

\section{Results}

The financial sector especially the banking industry has undergone a series of reforms since the entry into the $21^{\text {st }}$ century. However, these changes have been faced by a number of challenges including working and developing under a volatile economic environment, many privatizations in the banking industry, and the small banks having small profit margins as they try to compete with the major banks (Asian Development Bank, 2008). Many banks offer short term loans which affects the performance of small and medium-sized enterprises which require huge long-term loans. The industry has grown from a negative gross domestic product value to a positive one which has been a great contributor in the growth of the country's economy. The inflation rate has been on a constant fall especially after the changes and reforms in both economic and political systems of Mongolia. The country has also seen a number of reforms that have improved both the banking and the marketing sections of the Mongolian financial system.

\section{Discussion and Conclusion}

Considering the instability and the challenges faced by the current financial system in Mongolia, it is only logical to call for continuity in the reforming of this sector. It is also important to call for the support and the financing of the SMEs by offering them bigger and long-term loans. This year, the country is expected to suffer the adverse effects of coronavirus pandemic which have been felt and continues to be felt globally. There is expectation of a rise in government borrowing in regard to the gross domestic product, a reverse of what has been happening in the last few years. However, a recovery is expected as soon as possible if the effects will not persist for a long time.

In conclusion, the article has looked into the progressive advancement and development of Mongolian financial sector. It has identified the various changes in the financial indicators citing various issues handled by the government to bring normalcy and growth in this sector. It has described the various values of both institutions and markets in the financial system of the country and how 
they have changed over time. This is a comprehensive study on the various advancements in the financial industry that has given a glance into the past and the present of the Mongolian financial sector.

\section{Conflicts of Interest}

The author declares no conflicts of interest regarding the publication of this paper.

\section{References}

Asian Development Bank (2008). Evaluation Study: Financial Sector in Mongolia Transition to a Market Economy Built on Successful Financial Reforms, Rapid Sector Assessment. https://www.oecd.org/countries/mongolia/42227628.pdf

Bakkar, A. (n.d.). FinTech and the Future of Finance. The Global Advisory and Account in Network. https://www.hlb.global/fintech-and-the-future-of-finance

Bank of Mongolia (2012). Annual Report.

Barro, R. J., \& Sala-i-Martin, X. (1992). Convergence. Journal of Political Economy, 100, 223-251. https://doi.org/10.1086/261816

CEIC (n.d.). Mongolia Market Capitalization: \% of GDP. https://www.ceicdata.com/en/indicator/mongolia/market-capitalization--nominalgdp\# : :text=Mongolia's\%20Market\%20Capitalization\%20accounted\%20for,7.7\%20\%\%20in $\% 20$ the\%20previous\%20year

FRED Economic Data (2019). Volatility of Stock Price Index for Mongolia. https://fred.stlouisfed.org/series/DDSM01MNA066NWDB

Heritage (2020). 2020 Index of Economic Freedom: Mongolia.

Reid, R. (2010). Financial Development: A Broader Perspective.

Statista (2020). Domestic Credit to Private Sector as Share of GDP in Mongolia from 2010 to 2019.

https://www.statista.com/statistics/756407/domestic-credit-toprivate-sector-as-share-of -gdp-mongolia/\#statisticContainer

The Global Economy (n.d.). Mongolia: Bank Assets to GDP. Washington DC: The International Monetary Fund.

https://www.theglobaleconomy.com/Mongolia/bank_assets_GDP/\#: :text=Mongolia\% A\%20Bank\%20assets\%2C\%20percent $\% 20$ of\%20GDP\&text=The\%20average $\% 20 \mathrm{valu} \%$ 20for\%20Mongolia,from\%202017\%20is\%2060.6\%20percent

The World Bank (2016). Financial Development. https://www.worldbank.org/en/publication/gfdr/gfdr-2016/background/financial-devel opment

The World Bank (2020). Financial Depth. https://www.worldbank.org/en/publication/gfdr/gfdr-2016/background/financial-dept $\underline{\mathrm{h}}$

Trading Economic (2020a). Mongolia Money Supply M2. https://tradingeconomics.com/mongolia/money-supply-m2

Trading Economic (2020b). Mongolia-Bank Deposits to GDP. https://tradingeconomics.com/mongolia/bank-deposits-to-gdp-percent-wb-data.html

Trading Economic (2020c). Mongolia-Outstanding International Private Debt Securities to GDP. 
https://tradingeconomics.com/mongolia/outstanding-internationalprivate-debt-securit ies-to-gdp-percent-wb-data.html

Trading Economics (2020e). Mongolia Inflation Rate. https://radingeconomics.com/mongolia/inflation-cpi

Trading Economics (2020f). Mongolia GDP per Capita.

https://tradingeconomics.com/mongolia/gdp-percapita\#: :text=GDP\%20per\%20capita \%20in\%20Mongolia\%20is\%20expected\%20to\%0reach\%204584.00,according\%20to\%20 our\%20econometric\%20models

Trading Economy (2019). Mongolia-Bank Z-Score.

https://tradingeconomics.com/mongolia/bank-z-score-wb-data.html

Trading Economy (2020d). Mongolia-Outstanding International Public Debt Securities to GDP.

https://tradingeconomics.com/mongolia/outstanding-internationalpublic-debt-securiti es-to-gdp-percent-wb-data.html

Tsetsenzaya, T., Xiawei, Z., Hussain, Z., \& Shaheen, W. (2019). Economic Growth and Financial Development: An Empirical Analysis of Mongolian Economy. International Journal of Advanced Research, 7, 150-164. https://doi.org/10.21474/IJAR01/8308

Yueh, L. (2020). The 21st Century Global Economy. Oxford: University of Oxford. https://www.seh.ox.ac.uk/blog/the-21st-century-global-economy 